\title{
The Political System of the Republic of Turkey, Past and Present
}

\begin{abstract}
The first constitution of the Ottoman-Turkish Empire was adopted in 1876 - the Kânûn-l Esâsî (Eng. Fundamental Law). In its history, Turkey has had four constitutions. They were adopted in 1921, 1924, 1961, and 1982, with the latter being presently in force. Nowadays, the creation of a new constitution is the main issue on Turkey's political agenda. The government of Turkey and Mr. Recep Tayyip Erdogan want to amend the constitution, and envisage creating an executive presidential system (Tur. Başkanlık sistemi), similar to that of the Russian Federation and the United States. Critics are concerned about what Recep Tayyip Erdogan's motivation may be. This article analyzes the historical roots of the constitution, its amendments, the presidential system in Turkey and the arguments of the Republican People's Party (CHP) and Peoples' Democratic Party (HDP) against the adoption of a presidential system. The key issues that the authors address are the changes that could be made under Turkey's new constitution and whether all political power would be concentrated in president's hands.
\end{abstract}

Key words: Republic of Turkey, constitution, amendments, presidential system

\section{The First Ottoman Constitution and the First Assembly of 1876}

$\mathbf{T}$ he group of courtiers who overthrew Sultan Abdülaziz on May 30, 1876, by means of a government coup, brought Murat V to the throne, who promised a constitution. After a short time, Murat V was overthrown as well. On September 1, 1876, his brother, Sultan Abdulhamit II, who ascended the throne, was to face yet more challenges, as the Ottoman Empire was going through a critical time in its history (Sarikaya, 2016, p. 5).

The Ottoman-Turkish Constitution of 1876, declared by Sultan Abdulhamit II acting under pressure from a small group of reformist bureaucrats, provided, for the first time, some constitutional mechanisms to scrutinize the absolute power of the Sultan (Özbudun, 2011, p. 19). Abdulhamit created an exclusive committee of 28 people under the name of Meclis-i Mahsusa (Eng. Chamber of Deputies) on September 30, 1876 (K1liç, 2016, pp. 27-40). The most important development in the Constitution was the creation of a legislative assembly, which was at least partially elected by the people. The Ottoman legislature, known as the General Assembly (Osm. Meclis-i Umûtî), was composed of two chambers; the Senate (Osm. Heyet-i Ayan) and the Chamber of Deputies (Osm. Heyet-i Mebusan) (Özbudun, 2011, p. 19). The Chamber of Deputies established a sub-committee to draft the first constitution. On November 20, 1876, the committee, headed by Mithat Pasha, drafted the constitution and presented it to the Sultan (The Grand National..., 2015, p. 12). On December 23, 1876, Abdulhamit II promulgated the first constitution of the empire, which was known as Kanun-u Esâsî (the Main Law or the 
Fundamental Law) (Davison, 1963, pp. 358-400). Kanun-i Esasi consisted of a total of 119 articles (American Society of International Law, 1908, pp. 367-387) in 19 Chapters, and was compiled using translated elements of the constitutions of some other states, including Belgium, Poland and Prussia (The Grand National..., 2015, p. 12).

The Ottoman constitution, which was based on the Islamic principles, was always part of the state. Indeed, the first Article of Kanun-i Esasi reads: "The Ottoman Empire comprises the present territories and possessions and privileged provinces. It forms an indivisible whole, from which no part can ever be detached for any motive whatsoever" (American Society of International Law, 1908, p. 367). In an annotation to the first article, the author stated that there was no "Ottoman Nation" but an "Ottoman State;" it was a state encompassing various nations and nationalities. The second Article, regarding constitutional changes concerning the status of Istanbul, reads: "Istanbul is the capital of the Ottoman Empire. This city does not possess any privilege or immunity over any other cities of the Empire" (American Society of International Law, 1908, p. 367). The Ottoman Rule and the Caliphate under its protection would belong to the oldest members of the Ottoman Dynasty.

As Andrzej Adamczyk (2010) pointed out, "the 1876 Constitution was an imposed constitution, with its main aim being the Sultan's unrestricted sovereignty. In this case, the parliament, vested with insignificant powers, was not able to compete with the sovereign power of the Sultan, who put an end to the first constitutional period by suspending the Constitution two years after it came into force" (pp. 16-17). As Huseyin Korkut (2016, p. 122) indicates in his work, the Constitution of 1876 emphasized that Islamic principles were in favor of constitutional changes to prevent the violation of fundamental rights such as independence, equality and justice. Also, according to the work of Korkut (2016, p. 122), the Constitution was in harmony with the religion of Islam and, as such, it was important to preserve the administrative and institutional systems of the empire.

\section{The 1921 Constitution}

The Ottoman polity is as old as parliamentary history. The Chamber of Deputies and the Senate of the first Ottoman Assembly, which were established in 1877, had their own rules (Gençkaya, 1999, p. 4). In addition, the period of "National Liberation" was the most interesting era in Turkey's constitutional history and is full of constitutional improvements. Just after the arrest and deportation of many deputies with nationalist sympathies by the Allied occupation forces and the consequent prorogation of the Meclis-i Mebusân in Istanbul on March 18, 1920, Mustafa Kemal (who was the first President of the Republic of Turkey) authorized the election of a new parliament "with extraordinary powers." It was also stated that the assembly would convene in Ankara (Camadan, Kahya, Diksu, Kontaş, Ecevit, 1921, p. 17). Thereby, a new state government, separate from the Ottoman government, was established in Ankara. Thus, Ankara became the de facto seat of the provisional government in Turkey. This assembly was known as the Turkish Grand National Assembly, holding both legislative and executive power, and it was a "constituent and revolutionary" assembly (The Grand National..., 2015, p. 21). 
The first meeting of the Parliament was presided over by Sinop deputy Serif Bey, who was the oldest member in the Assembly and used the phrase "Grand National Assembly" in his opening speech. The Cabinet decree on "the Composition of the Grand National Assembly of Turkey," dated February 3, 1921, also called the Parliament the "Grand National Assembly of Turkey" (Tur. Türkiye Büyük Millet Meclisi, TBMM) (Camadan et al., 1921, p. 17). Mustafa Kemal Pasha was elected the Speaker of the Assembly during the second sitting on April 24, 1920. A provisional Executive Committee, headed by Mustafa Kemal Pasha, was formed on April 25, 1920. The Law on Treason was adopted. It stipulated that "the objective of the Assembly is to save the country, caliphate and monarch from foreign invaders" (Camadan et al., 1921, p. 17). It must be emphasized that those who objected to the law were considered traitors (Camadan et al., 1921, p. 17).

The principles that the government of Ankara was based on needed clarification. Therefore, Teşkilat-ı Esasiye Kanunu (the Constitution of 1921) came into force. Nevertheless, during that period, the Ottoman Constitution of 1876 was not abrogated; as the Constitution of 1921 came into force, a "dual constitutional period" began. Teşkilat-l Esasiye Kanunu was a simple document - it included only 23 articles - used for a brief period, from 1921 to 1924 (Topukcu, 2015, p. 60). In this context, it was a constitution for wartime (the War of National Liberation, 1919-1922) and it described the main structure of the government, including local administration, without any reference to rights and freedoms (Gençkaya, Özbudun, 2009).

The Constitution of 1921, drafted amid the struggle against the victorious World War I powers that invaded "the Anatolian heartland," served as a preliminary document intended to unify all inhabitants against foreigners. Sovereignty, it stated simply, belonged to the people. More momentously, the constitution also contained provisions for provincial autonomy (Barkey, Kadioglu, 2011). In this respect, Ozan Örmeci (2012) draws attention to the fact that the Constitution of 1921 expressed "the radical revolutionary transformation of Turkish society by establishing the constitutional principle that the Grand National Assembly of Turkey (Tur. Türkiye Büyük Millet Meclisi, TBMM) is the sole and true representative of the nation. In order to achieve this goal, it established an assembly government system in which all the powers of sovereignty were embodied in the parliament."

\section{The 1924 Constitution}

On November 1, 1922, TBMM abolished the Ottoman Sultanate ${ }^{1}$ and Sultan Mehmed VI left the country. Consequently, the Caliphate, bound in the Ottoman Empire to the Sultanate, could no longer exist in Turkey as an institution of spiritual guidance for the

${ }^{1}$ The government of Ankara, through decisions no. 307 and no. 308, declared the abolition of the Sultanate and the end of the Ottoman Empire, but due to continuing foreign occupation, it postponed any act that would abolish the Caliphate until 1924. On March 3, 1924, the Caliphate and the Ministry of Religion and Religious Foundations were abolished under Law no. 431. Pursuant to Law no. 430, on the Unification of the Educational System, the duality of secular and religious education was put to an end; and on April 8, 1924 the unification of the Judiciary was established (Öktem, Uzun, 2015, p. 703). 
Muslim diaspora (Adamczyk, 2010, p. 19). About a year later, on October 29, 1923, the Republic was officially proclaimed (Gençkaya, Özbudun, 2009, p. 10). Mustafa Kemal Pasha became the first President, and İsmet İnönü became the first Prime Minister.

After the proclamation of the Turkish Republic, the state clearly needed a new constitution. Özbudun explains this situation in the following way: the Constitution of 1921 was not meant to be a constitution in the full sense of the word; rather, it was a brief document dealing only with the most urgent constitutional problems of the moment (Gençkaya, Özbudun, 2009, p. 10). The new Constitution was adopted on April 20, 1924, under the leadership of Mustafa Kemal Pasha (Öktem, Uzun, 2015, p. 703). The Constitution of 1924, officially titled the Constitution of the Republic of Turkey, replaced the Constitution of 1921 . The preparation and enactment of the constitution happened so quickly that neither the public nor any advocacy group was able to influence the shape of the constitution. It was inspired by the constitutions of 1875 in France and 1921 in Poland (Kaya, 2011). Deniz Polat $(2014$, p. 6) stated that the 1924 Constitution represented a more centralist unitary state model. However, the Constitution did not refer to the unitary state per se.

The Second Constitution of 1924 was a product of the military-bureaucratic elites; it came into effect after the promulgation of the Republic in 1923 (Uran, Pasquino, 2015, p. 89). Regarding the characteristics of the Constitution of 1924, it is necessary to mention briefly that the period which began in 1922 is known as the "Kemalist Revolution/Turkish Revolution/Atatürk Revolution/Kemalist Reforms" period (Topukcu, 2015, p. 61). The Constitution of 1924 was drafted by all powers in the unicameral legislature, which was totally dominated by a single party - Cumhuriyet Halk Partisi, CHP (Eng. Republican People's Party, RPP). It did not adopt the principle of constitutional review and did not offer effective guarantees for fundamental rights and liberties (Uran, Pasquino, 2015, p. 89).

As a result of the Constitution of 1924, a republican system of government was established, and certain fundamental rights and liberties were recognized. With an amendment in 1928, the reference to state religion was removed altogether from the text of the Constitution, and, in 1937, the Constitution was amended to officially recognize Turkey as a "secular" republic. On February 5, 1937, the Assembly adopted the Turkish phrase for laicism, from the French principle of secularism (Uzun, 2010, pp. 392-395; Varol, 2011, p. 1258).

\section{The 1961 Constitution}

The first coup in the Turkish Republic took place on May 27, 1960. Following this coup d'état which changed Turkey's political life, the GNAT was dissolved, the President of the Republic of Turkey Celal Bayar, Prime Minister Adnan Menderes and also all the ministers and members of the Assembly were imprisoned and, later, Adnan Menderes was hanged (Gürsoy, 2014). Milli Birlik Komitesi (Eng. The Committee of National Unity, CNU) assumed all the powers of the Parliament by means of a provisional constitution and began to rule the country. Executive power was exercised by ministers appointed by the Committee of National Unity (Grand National Assembly of Turkey, n.d.). 
The main goal of the CNU was to destroy the Democratic Party and to prepare a new constitution.

The Constitution of 1961 was a result of the military coup and, in this sense, the Constitution was drafted to suit the needs of those in power. Following the coup, work on the new constitution started at once, when a committee of five professors of law from the University of Istanbul was appointed to prepare a draft, and, on January 6, 1961, the new draft was presented to the Constituent Assembly (Tur. Kurucu Meclis). The Constitution of 1961 was completed in May and was approved by $61 \%$ of voters in a referendum in July (Yapp, Dewdney, n.d.). The new Constitution stipulated a typical parliamentary system. The Constitution thus established a two-chamber (bicameral) parliament, consisting of the Senate and the National Assembly (Yapp, Dewdney, n.d.).

In this context, the Constitution of 1961 remained in effect until 1980. During that period, it was amended seven times, with one of the amendments found procedurally unconstitutional by the Constitutional Court. Of the remaining six amendments, those of 1971 and 1973 were particularly important in their nature and scope.

\section{The 1982 Constitution}

However, by the 1980s, a new regime had developed, in which the aim of maintaining public order was given priority, and in which the Constitution would strengthen the position of the executive against other authorities (Sencer, 1986, p. 17). As the result of these developments, on September 12, 1980, the Turkish Armed Forces, TAF (Tur. Türk Silahlı Kuvvetleri, TSK) launched a successful military coup d'état (Dursun, 2005) - the third in the history of the Turkish state (Dursun, 2005).

The Turkish Constitution of 1982 - which is presently in force - was enacted after a military coup on September 12, 1980. The new Constitution was suspended, political parties were banned, and the leaders and management groups of political parties were detained and tried. The government under Prime Minister Süleyman Demirel was dismissed, the Parliament was dissolved, and several individuals were banned from politics (The Grand National..., 2015, p. 31).

The 1982 constitutional referendum was combined with a presidential election. A "yes" vote for the Constitution was also an endorsement of the presidency of Kenan Evren (the only candidate) for a seven-year period. Moreover, the National Security Council members implied that, if the draft were to be rejected, the NSC regime would continue indefinitely. Under these circumstances, on November 7, 1982, the Constitution was approved by $91.37 \%$ of votes cast (Gençkaya, Özbudun, 2009, p. 20).

There is an ongoing debate about changing the current constitution, which has already been amended sixteen times. Ten of these amendments were implemented under the rule of the Adalet ve Kalkınma Partisi, AKP (Eng. Justice and Development Party) (Kaya, 2011). On October 3, 2001, the 1982 Constitution was amended extensively by the GNAT. On October 17, 2001, these amendments came into effect after their publication in the Official Gazette. 34 articles were changed completely (Türkiye Cumhuriyeti..., 2001, 3 October). In addition, the 1982 Constitution was amended by the GNAT in 1987, 1993, 1995, 1999 (twice), 2001 and 2002 (Gönenç, 2004, pp. 89-109). The 
1982 Constitution has been amended several times since the day it was approved, and it has changed fundamentally, especially with the "harmonization laws" passed within the framework of the EU accession process. Most recently, the Constitution was amended substantially in 2010. Considerable efforts have been made to completely transform this Constitution.

In more recent times, the constitutional amendments of 2010 changed 24 articles and added two provisional articles. The AKP proposed a set of constitutional amendments, which failed to achieve the necessary majority in the assembly. However, they became the subject of a nationwide referendum on September 12, 2010, in which 49.5 million people, out of Turkey's population of 74.8 million, were eligible to vote. The referendum was passed with $58 \%$ "yes" votes against $42 \%$ "no" votes (Kalaycioglu, 2011, pp. 1-22; $\mathrm{BBC}, 2010)$.

\section{The presidential system (Tur. Başkanlık sistemi)}

The ruling AKP has sought to introduce a presidential system to replace the current parliamentary model since President Recep Tayyip Erdogan was chosen the first head of state elected directly by popular vote (Merkezi, 2016). Since he was elected President of Turkey in August 2014, the spectacular career of Recep Tayyip Erdoğan has entered a new phase, and the same could be said for the "New Turkey" he has proclaimed (Scharfe, 2015). However, with the election of the President by public vote, the President has started using his authority, granted by the Constitution, more actively. According to Turan (2016), this situation triggered discussion on a semi-presidential system, which was technically what Turkey currently had. In order to show that a semi-presidential system $^{2}$ is practiced in Turkey, a description of the semi-presidential system should be first made (Turan, 2016).

Turkey's Parliament is set to decide whether the country will consider one of the greatest transformations since the beginning of the Republic, i.e. changing to a presidential system. The government has submitted a constitutional amendment plan to Parliament. The changes include doing away with the role of the Prime Minister and having a unitary presidential system, and separating and defining the roles of the three branches of government, with the president only in charge of the executive branch (Daventry, 2016). The referendum introduced one amendment with 18 articles to the Turkish constitution. Of the numerous changes that were proposed, nine are of particular significance:

1) The Prime Ministry will be abolished;

2) The President will replace the Prime Minister as the executive;

3) An unspecified number of Vice Presidents could be assigned by the President. The President will appoint ministers from outside the Parliament. Members of Parliament cannot serve as ministers;

2 "The semi-presidential system is not accepted by some lawyers and political scientists, and it is disputed whether it is a type of parliamentary system at all. The debate on whether the system practised in Turkey today is semi-presidential or not has become even more heated even after the election of President Recep Tayyip Erdoğan in a public vote in 2014” (Turan, 2016). 
4) The President will have the authority to issue statutory decrees; prepare the budget; declare a state of emergency; and call early presidential and parliamentary elections;

5) The amendment dictates that the announcement of elections automatically triggers both presidential and parliamentary elections at the same time;

6) The number of MPs will increase from 550 to 600 , and the minimum age of political candidacy will decrease from 25 to 18 ;

7) Parliament will no longer be able to call for an inquiry against ministers, but will be able to initiate an impeachment process against the President with a majority vote instead;

8) The President will be able to serve as the chairman of a party;

9) The President will be able to appoint the majority of the judiciary, directly or indirectly (Gungen, Bag, 2017).

The President will have a term of five years and will be able to remain the leader of their party. The President will also be able to directly appoint: the heads of army and intelligence agencies, university presidents, bureaucrats and some top judicial bodies (Yalcin, 2016). The "yes" campaign is led by the ruling Justice and Development Party, in alliance with the National Movement Party (MHP), and is supported by the President and other public officials. Any constitutional change needs the support of at least 367 deputies in the 550-seat assembly to be passed immediately, and of 330 to go to a referendum. The AKP has 317 seats, and the MHP - 39 (Pamuk, 2016). Most of the opposition parties, including the CHP (Republican People's Party) and the HDP (People's Democratic Party), are part of the "no" campaign (IFES, 2017).

As mentioned above, Turkey's current constitution was drafted after a military coup in 1980. It strengthened the President's role, giving him the power to step in to avoid future political stalemates. The government perceives the current presidential and parliamentary system as problematic due to the crisis of "double legitimacy," and it believes that entering into "fragile coalitions" can make the government weaker. It claims that the new system will be "more efficient" and will help Turkey to develop more quickly. However, critics raise doubts, claiming that there will be too much concentration of power, allowing for potential abuse of executive powers without parliamentary approval, and that this is a move towards authoritarian rule. Does the Republic of Turkey need to change the Constitution, and will the presidential system be beneficial for its development and democracy or harmful? This is a critical turning point for Turkey. The leader of the main opposition party, the Republican People's Party, Kemal Kılıçdaroğlu, said in an interview in the Voice of Russia on November 14 last year that "[i]mposing a presidential system on Turkey will cause a disaster in the country, and we are against the presidential system categorically. I have said that without knowing about the presidential system which the AKP has proposed; commenting about it would not be right. We don't know the details" (Hürriyet Daily News, 2016). According to Bülent Tezcan, who is the deputy chairman of the CHP, the introduction of this kind of system would bring powers back "to the palace," restoring the powers that were taken from the Ottoman Sultan a century ago (Agence France-Presse in Istanbul, 2017). Kanatli (2016), too, is critical of the presidential system. He pointed out that "[t]he Presidential System Draft put forward by the AKP, and the current practices of the governing party and the President of the Republic clearly indicate that this model will not relieve Turkish political, economic, and social 
crises. The Turkish type of presidential system will bring about an authoritarian type of regime, which will ignore the chief principle of the rigid separation of powers and will lead to the legislative and judicial branches being dominated by the executive, further polarization of society under the mask of stability, and undermining the democratic gains in Turkish political life" (p. 127).

\section{The CHP's Arguments against the Proposition}

\begin{tabular}{|c|c|}
\hline \multicolumn{2}{|r|}{ The CHP's Arguments Against the Proposition } \\
\hline & A disproportionate increase in the President's authority. It opens the way for one-man rule. \\
\hline & $\begin{array}{l}\text { Transition to the presidential system is advocated due to its success in the US, but what is being pro- } \\
\text { posed is different from the US system - the draft destroys separation of powers and increases the execu- } \\
\text { tive branch's powers extraordinarily. }\end{array}$ \\
\hline & $\begin{array}{l}\text { The draft is a step towards a system change, rather than a mere constitutional revision. If passed, the new } \\
\text { changes will lead the way to an authoritarian Turkey. }\end{array}$ \\
\hline & $\begin{array}{l}\text { There are no checks and balances in the proposed system. The President's jurisdiction is extended } \\
\text { without restrictions. }\end{array}$ \\
\hline & $\begin{array}{l}\text { The election of the President by popular vote does not guarantee the full representation of the nation. } \\
\text { The curbing of checks and balances could lead to arbitrary rule in the new system. }\end{array}$ \\
\hline & $\begin{array}{l}\text { In the new system, executive power is gathered in the person of the President, whereas, currently, it rests } \\
\text { in the government as well. The system proposes one-man rule. }\end{array}$ \\
\hline & $\begin{array}{l}\text { The appointment and dismissal of Ministers and Vice Presidents are within the mandate of the President, } \\
\text { and parliamentary approval of their appointment is not necessary in the new system. Moreover, the leg- } \\
\text { islature is further weakened by leaving it bereft of its right to dismiss or to oversee Ministers. The insti- } \\
\text { tutions of the vote of confidence and of the questioning of the Council of Ministers will be abolished. }\end{array}$ \\
\hline & $\begin{array}{l}\text { Under this proposed draft, should the Parliament wish to put the President on trial, the process can be set } \\
\text { in motion by the signatures of } 301 \text { deputies in the proposed } 600 \text {-seat parliament. Parliament will be able } \\
\text { to set up a commission of inquiry by a secret ballot of } 360 \text { deputies. If the inquiry commission decides to } \\
\text { send the President to the Supreme Court to face trial, the President will only be tried following a secret } \\
\text { ballot of } 400 \text { deputies. }\end{array}$ \\
\hline
\end{tabular}

Source: TRT WORLD, 2017a, p. 17.

\section{The HDP's position}

\begin{tabular}{|l||}
\hline \multicolumn{1}{|c||}{ The HDP's position } \\
\hline- The HDP boycotted the parliamentary voting. \\
\hline- They argue that the constitutional amendment will result in one-man rule. \\
The HDP announced that they are going to campaign for 'no' in the referendum and that they plan to \\
cemand a "demarately from the CHP, because the CHP's intention is to maintain the status quo, while they \\
deman and pluralist constitution." \\
They also claim that making constitutional changes while a number of HDP MPs are detained means \\
ignoring part of society.
\end{tabular}

Source: TRT WORLD, 2017a, p. 17.

The spokesperson of the pro-Kurdish opposition party, the HDP, Ayhan Bilgen, stated that they "recommend (Turkey's current) parliamentary system. We believe that a parliamentary system will move democratization forward. But making the content of the constitution a taboo topic, or any approach which claims that 'We don't discuss the presidential (system), this and that,' will not comply with a democratic constitutional process" (Hürriyet Daily News, 2015). Mithat Sancar, who is an MP for the HDP, responded with 
the following words: "The only leader who can maintain a good 'no' campaign against Erdoğan is Selahettin Demirtaş... Demirtaş’ arrest means that Erdoğan has pushed his most powerful rival out of the game" (Shaheen, 2017a).

Based on this, President Recep Tayyip Erdogan noted that "the advantage of a presidential system is that it would give Turkey the opportunity to develop much more rapidly. The US and Russia are two important examples, even though their systems function differently. Let's establish a Turkish-style presidential system for Turkey. This will give Turkey an opportunity to develop much faster, so I defend it" (Kesgin, 2016). However, when hosting mukhtars - local officials who keep official records of communities - at the presidential palace, President Erdogan claimed that "Mustafa Kemal, Süleyman Demirel (9th President of Turkey from 1993 to 2000), Necmettin Erbakan (who was the Prime Minister of Turkey from 1996 to 1997) and Alparslan Türkeş (who was a Turkish politician, the founder and president of the Nationalist Movement Party) all lacked the time and power to be able to change the system. That is not my personal wish at all. Ultimately, everything will depend on how long the elected president will serve and how many times he/she can be elected. While the global system is going through a dramatic change, it is very difficult for Turkey to turn this change into an opportunity within the current system" (Daily Sabah, 2015). After long discussions, on December 30, 2016, the Parliamentary Constitutional Committee approved a bill proposing a set of constitutional changes, including a switch to a presidential system of government in Turkey. Finally, the Committee completed the approval process, rejecting three of 21 proposals in total. The bill is now expected to be put to a vote in Parliament during the second week of January 2017, and there will be two rounds of voting in which the deputies first vote on each article and then vote for the package as a whole (Daily Sabah, 2016).

\section{Final Result of the Turkish Referendum 2017}

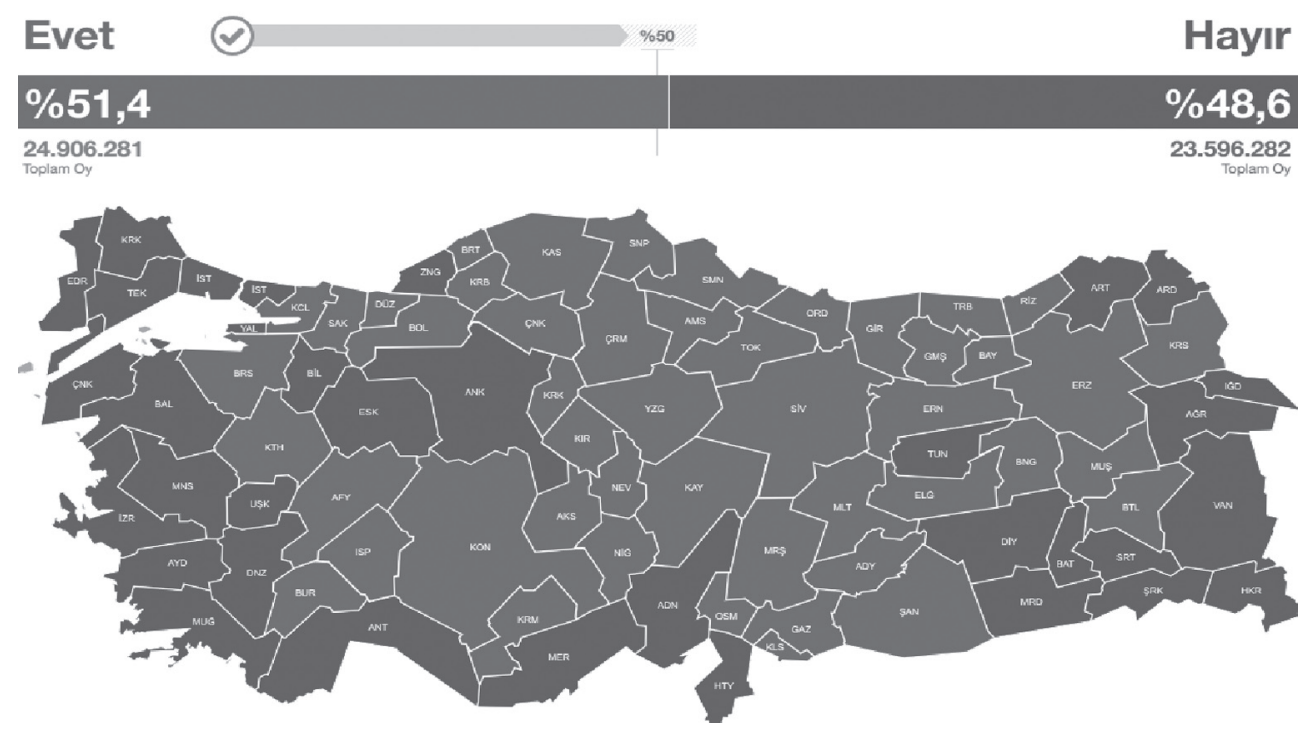

Source: Merkezi, 2017. 
On April 16, 2017, Turkish citizens went to the polls to cast their votes regarding the new constitution. The final results released by the High Electoral Board (Tur. Yüksek Seçim Kurulu, YSK) show the 'Evet' ('Yes') campaign received $51.41 \%$ of the votes, while the 'Hayır' ('No') votes garnered 48.59\% (25,157,025 "Evet" against 23,777,09 "Haylr") (TRT WORLD, 2017b). After the victory, Recep Tayyip Erdogan said that "[t] he fact that the outcome of the referendum is 'yes' shows that our people accept the presidential system of government." Prime Minister Binali Yildirim, whose position will be abolished when most of the constitutional changes take effect, also chose to welcome the result without waiting for a formal announcement by the YSK (Aliriza, 2017). On the other hand, the chairman of the main opposition party, the Republican People's Party, Kemal Kilicdaroglu said: "You cannot change the rules of the game in the middle of the game," adding that the board had "cast a shadow over the results." The HDP (pro-Kurdish People's Democratic Party) also claimed they had information about voter fraud in up to $4 \%$ of the ballots. Both parties said they would appeal against the result (Agerholm, Stevenson, 2017). On April 17, 2017, a series of complaints were filed to different authorities by opposition parties, civil society and professional associations. Amongst the complaints were two criminal complaints lodged against the YSK members for misconduct in office regarding the YSK's decision to count unstamped ballots as valid (OSCE, 2017). Eventually, on April 19, the YSK put an end to any poll disputes, rejecting all of the opposition's objections to the results of the April 16 constitutional referendum (EIY, 2017). The spokeswoman of the CHP party, Selin Böke, stated that "[w]e don't and won't recognize this referendum result," adding that the Republican People's Party would exercise all its democratic rights including the possibility of "seceding" from Parliament (Shaheen, 2017b).

\section{Conclusions}

The Turkish Armed Forces have traditionally played an influential role in the country's political affairs and contributed to the adoption of the constitution. Turkey is now the 17th largest economy in the world. It is larger than Saudi Arabia. The capability of the Turkish army is probably the best in Europe. Turkey is among the world's most developed countries, but most recently, on July 15, 2016, a military coup was attempted in Turkey against Erdoğan's government. The coup failed. It was a great victory for the democratically elected government of Turkey; the defiant citizens of Turkey defended their democracy. We can say that, since the 1960s, Turkey has experienced a coup about once every 10 years. The proceedings of the last coup of July 15 changed this trend. This is because Turks do not want a return to military rule.

In the meantime, the government of the AK Party, the MHP, agreed to adopt a presidential system. As a result, the Parliamentary Constitutional Committee approved the amendments to the Constitution. The changes essentially shift Turkey's ruling system from a parliamentary to a presidential one. Turkey has been ruled by a non-partisan President serving alongside a legislative Prime Minister since at least 1923. In this system, the Prime Minister holds most power, but it once happened that a Prime Minister resigned from his post to assume the office of President. 
It should be pointed out that Turkey is facing big changes in the future after the referendum on the presidential system in 2017. Turkey voted 'Evet' for a presidential system and 18 other constitutional changes. Most of the provisions of the constitutional amendments will be in force by 2019. In May 2017, Erdogan was re-elected the head of the ruling AKP, which made him the first President to lead a party since 1950. This means that President Erdogan reasserted his control over the AKP. On April 16, 2017, for the first time in fourteen years, Ankara, Istanbul and Izmir - the three largest cities - voted against the AKP, which is tantamount to voting against Erdogan. ${ }^{3}$ The President is losing votes in key cities. Therefore, the municipal, parliamentary and presidential elections planned for November 3, 2019 will play an essential role. The next elections are bound to be extremely difficult for Erdogan.

\section{Bibliography}

\section{Monographs:}

Camadan A., Kahya G., Diksu M., Kontaş S, Ecevit I. S. (n.d), Turkish War of Independence, 1921.

Davison R. H. (1963), Reform in the Ottoman Empire, 1856-1876, Princeton University Press, New Jersey.

Dursun D. (2005), 12 Eylül Darbesi, Şehir Yayınları, Istanbul.

Gençkaya Ö. F., Özbudun E. (2009), Democratization and the Politics of Constitution-Making in Turkey, Central European University Press, Budapest.

Gürsoy N. B. (2014), 27 Mayıs Darbesi ve Bizler, Timas Yayinlari, Istanbul.

\section{Articles and studies in journals:}

Adamczyk A. (2010), Kemalism and Modern Turkey, “Acta FF,” no. 2.

Gençkaya Ö. F. (1999), Reforming Parliamentary Procedure in Turkey, “M.E.S.,” no. 48.

Gönenç L. (2004), The 2001 Amendments to the 1982 Constitution of Turkey, "Ankara Law Review," vol. 1 , no. 1.

Kalaycioglu E. (2011), Kulturkampf in Turkey: The Constitutional Referendum of 12 September 2010, "South European Society and Politics," no. 17.

Kanatli M. (2016), The Practicability of the Presidential System in Turkey and the Discussions over Never Ending Dreams of Democracy, "Turkish Journal of TESAM Academy," vol. 3, no. 2.

Kılıç S. (2016), 1876 Meclis-i Mebusanı ve Seçim Hazırlıkları, "Devlet," no. 466.

Korkut H. (2016), Critical Analysis of the Ottoman Constitution (1876), "Epiphany: Journal of Transdisciplinary Studies," vol. 9, no. 1.

Polat D. (2014), Understanding of the Turkish Constitutional Court Regarding Unitary State, "The Turkish Yearbook of International Relations," vol. 45.

Sencer M. (1986), From the Constitution of 1961 to the Constitution of 1982, "Turkish Yearbook of Human Rights," no. 7/8.

Topukcu A. (2015), The Processes and the Principles of Constitutional Design in Turkey, "Central and Eastern European Legal Studies," no. 1.

Uran P., Pasquino P. (2015), The Guardian of the Turkish Constitution: A Special Court, "Journal of Politics and Law," vol. 8, no. 2.

${ }^{3}$ The "Hayir" vote prevailed in Istanbul, Ankara and İzmir with $51.3 \%, 51.1 \%$ and $68.8 \%$ of the vote respectively. 
Uzun M. C. (2010), The Protection of Laicism in Turkey and the Turkish Constitutional Court: The Example of the Prohibition on the Use of the Islamic Veil in Higher Education, "Penn State International Law Review," vol. 28, no. 3.

Varol O. O. (2011), The Origins and Limits of Originalism: A Comparative Study, "Vanderbilt Journal of Transnational Law," no. 44.

\section{Articles and studies in collective works:}

Öktem E., Uzun M. C. (2015), IACL National Report: The Republic of Turkey, in: Religion and the Secular State: National Reports, eds. J. Martínez-Torrón, W. Durham, Servicio de Publicaciones de la Facultad de Derecho de la Universidad Complutense, Madrid.

Özbudun E. (2011), Constitutional Law, in: Introduction to Turkish Law, eds. T. Ansay, D. Wallace, Kluwer Law International, Alphen aan den Rijn.

\section{Documents:}

American Society of International Law (1908), The Ottoman Constitution, Promulgated the 7th Zilbridje, 1293 (11/23 December, 1876), "The American Journal of International Law," vol. 2, no. 4, Supplement: Official Documents.

OSCE (2017), Republic of Turkey Constitutional Referendum 16 April 2017. OSCE/ODIHR Limited Referendum Observation Mission Final Report, OSCE Office for Democratic Institutions and Human Rights, Warsaw.

Türkiye Cumhuriyeti Anayasasının Bazı Maddelerinin Değiştirilmesi Hakkında Kanun (2001, October 3), "Resmi Gazete," Sayı: 24556, Kanun no. 4709.

\section{Internet references:}

Agence France-Presse in Istanbul, Turkish Parliament Debates Controversial New Constitution, 9.01.2017, https://www.theguardian.com/world/2017/jan/09/turkish-parliament-controversialnew-constitution-recep-tayyip-erdogan, 11.09.2017.

Agerholm H., Stevenson C., Turkey's President Erdogan Claims Victory in Vote to Give Him Sweeping New Powers - But Opposition Cries Foul, 16.04.2017, http://www.independent.co.uk/ news/world/europe/turkey-referendum-president-recep-tayyip-erdogan-supreme-power-latestcount-a7686511.html, 17.09.2017.

Aliriza B., After the Referendum, 8.05.2017, https://www.csis.org/analysis/after-referendum, 15.09.2017.

Barkey H., Kadioglu D., The Turkish Constitution and the Kurdish Question, 1.08.2011, http://carnegieendowment.org/2011/08/01/turkish-constitution-and-kurdish-question/4e14, 20.12.2016.

BBC, Q\&A: Turkey's Constitutional Referendum, 12.09.2010, http://www.bbc.com/news/world-europe-11228955, 2.01.2017.

Daily Sabah, Comparison of 1982 Constitution to Changes Offered in New Package, 30.12.2016, http:// www.dailysabah.com/legislation/2016/12/31/comparison-of-1982-constitution-to-changesoffered-in-new-package, 30.12.2016.

Daily Sabah, Erdoğan: Presidential System Necessary to Achieve Goals, 11.03.2015, http://www. dailysabah.com/politics/2015/03/11/erdogan-presidential-system-necessary-to-achieve-goals, 30.12.2016.

Daventry M. S., Explainer: Turkey's New Presidential System, 12.12.2016, http://www.jamesinturkey. com/explainer-turkeys-new-presidential-system/, 29.12.2016.

EIY, In a 'Surprising' Move, Turkish Electoral Council Swiftly Rejects All Referendum Appeals, 19.04.2017, https://washingtonhatti.com/2017/04/19/in-a-surprising-move-turkish-electoralcouncil-rejects-swiftly-all-referendum-appeals/, 18.09.2017.

Grand National Assembly of Turkey, History, n.d., https:/global.tbmm.gov.tr/index.php/TR/yd/icerik/ 12, 30.12.2016. 
Gungen D., Bag T., The 2017 Turkish Constitutional Referendum, 19.04.2017, http://apcoworldwide. $\mathrm{com} /$ docs/default-source/default-document-library/Thought-Leadership/turkey-post-referendum-apco-worldwide.pdf, 21.09.2017.

Hürriyet Daily News, HDP Makes Clear It Does Not Favor Presidential System, 4.11.2015, http:// www.hurriyetdailynews.com/hdp-makes-clear-it-does-not-favor-presidential-system.aspx?pag $\mathrm{eID}=238 \& \mathrm{nID}=90744 \&$ NewsCatID $=338,14.09 .2017$.

Hürriyet Daily News, Presidential System Will Bring Turkey to Ruination: CHP Leader, 14.11.2016, http://www.hurriyetdailynews.com/presidential-system-will-bring-turkey-to-ruination-chpleader-.aspx?pageID=238\&nID=106096\&NewsCatID=338, 30.12.2016.

IFES, Elections in Turkey. 2017 Constitutional Referendum. Frequently Asked Questions, 10.04.2017, https://www.ifes.org/sites/default/files/2017_ifes_turkey_constitutionalreferndum_faqs.pdf, 17.09.2017.

Kaya Ö., On the Way to a New Constitution in Turkey, November 2011, http://library.ifes.de/pdffiles/ bueros/tuerkei/12220.pdf, 27.12.2016.

Kesgin H. (2016). Erdogan: Presidential System to Speed Turkey's Progress, 11.11.2016, http://aa.com. tr/en/todays-headlines/erdogan-presidential-system-to-speed-turkey-s-progress/683247, 2.01.2017.

Merkezi H., Presidential System for Stability in Turkey, Says PM, 19.11.2016, http://www.yenisafak. $\mathrm{com} / \mathrm{en} /$ news/presidential-system-for-stability-in-turkey-says-pm-2566884, 2.01.2017.

Merkezi H., Referandum seçim sonuçları ve analizleri! Seçim 2017 seçim sonuçları burada, 17.04.2017, http://www.yenisafak.com/referandum-secim-sonuclari-ve-analizleri-secim-2017-secimsonuclari-burada-h-2645057, 10.06.2017.

Örmeci O., Turkish Constitutions (1921, 1924, 1961, 1982) in Comparative Perspective, 24.06.2012, http://politikaakademisi.org/2012/06/24/turkish-constitutions-1921-1924-1961-1982-in-comparative-perspective/, 21.12.2016.

Pamuk H., Turkey's Erdogan Could Govern until 2029 under Plans to Change Constitution, 11.11.2016, http://www.euronews.com/2016/11/11/turkeys-ruling-akp-hopes-for-nationalist-support-onconstitutional-change-pm-says, 30.12.2016.

Sarikaya A., Hungarian People's Attitudes to Grof Andrassy Gyula before-during-after Bosnia and Herzegovina Was Annexed by the Austro-Hungarian Monarchy, April 2016, http://culturalrelations. org/Resources/2016/ICRP_RPS-Sarikaya-Hungarian_peoples_attitudes-2016.pdf, 30.12.2016.

Scharfe P., Erdoğan's Presidential Dreams, Turkey's Constitutional Politics, February 2015, http:// origins.osu.edu/article/erdo-s-presidential-dreams-turkey-s-constitutional-politics/page/0/0, 25.12.2016.

Shaheen K., Debating in Whispers: Opposition Fearful ahead of Turkish Referendum, 2.03.2017a, https://www.theguardian.com/world/2017/mar/02/debating-in-whispers-opposition-fearfulahead-of-turkish-referendum, 14.09.2017.

Shaheen K. Turkish Election Board Rejects Calls to Annul Referendum Result, 19.04.2017b, https:// www.theguardian.com/world/2017/apr/19/turkish-election-board-recep-tayyip-erdogan-referendum, 18.09.2017.

The Grand National Assembly of Turkey, 2015, https://www.tbmm.gov. tr/yayinlar/prestij_kitap_ ingilizce_s.pdf, 26.12.2016.

TRT WORLD, Turkey's Constitutional Reform, February 2017a, https://www.trtworld.com/referendum/images/key/research.pdf, 23.09.2017.

TRT WORLD, Official Results of Turkey's Referendum Released, 17.04.2017b, http://www.trtworld. com/turkey/official-results-of-turkeys-referendum-released-344439, 23.09.2017.

Turan H. C., Government Systems Discussions in Republic of Turkey, 2016, https://www.westeastinstitute.com/wp-content/uploads/2016/09/H.-C.-Turan.pdf, 20.12.2016. 
YalcinZ.,BaşkanlıkdeğilCumhurbaşkanlığı,16.11.2016,http://www.sabah.com.tr/gundem/2016/11/16/ baskanlik-degil-cumhurbaskanligi, 29.12.2016.

Yapp M. E., Dewdney J. C., The Military Coup of 1960, n.d., https://www.britannica.com/place/Turkey/The-military-coup-of-1960, 30.12.2016.

\section{System polityczny Republiki Turcji. Przeszłość i teraźniejszość}

\section{Streszczenie}

Pierwsza konstytucja Imperium Osmańskiego uchwalona została w 1876 r. - Kânûn-ı Esâsî (pol. ustawa zasadnicza). Cztery tureckie konstytucje przyjmowano kolejno w latach: 1921, 1924, 1961, i 1982 r. Priorytetowym zadaniem i zarazem najważniejszą kwestią ustrojową dla tureckiego rządu i prezydenta Recepa Tayyipa Erdogana było przygotowanie rewizji obowiązującej konstytucji zakładającej wprowadzenie systemu prezydenckiego (tur. Başkanlık sistemi), na wzór modelu obowiązującego w Federacji Rosyjskiej czy w Stanach Zjednoczonych. Celem artykułu jest omówienie historycznych korzeni konstytucji Republiki Turcji. Autorzy analizują wprowadzone do ustawy zasadniczej poprawki, omawiając przy tym kształt tureckiego systemu prezydenckiego. Ponadto w niniejszym opracowaniu przedstawiono argumenty przeciwników reformy systemu politycznego w Turcji podnoszone przez zwolenników Republikańskiej Partii Ludowej (CHP) oraz Demokratycznej Partii Ludowej. Celem artykułu jest również analiza zmian, które stanowią efekt ostatniej reformy konstytucyjnej w Turcji. Rozważania koncentrują się także wokół odpowiedzi na pytanie o zakres rzeczywistej władzy prezydenckiej R. T. Erdogana.

Słowa kluczowe: Republika Turcji, konstytucja, poprawki, system prezydencki 